\title{
Turkey: facing \\ a new millennium \\ Coping with \\ intertwined conflicts
}

$\star$

AMIKAM NACHMANI 


\section{TURKEY: FACING A NEW MILLENNIUM}

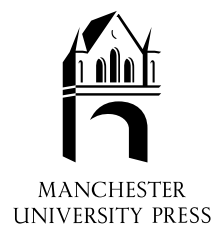




\section{EUROPE}

\section{IN \\ CHANGE}

already published

Committee governance in the European Union

THOMAS CHRISTIANSEN AND EMIL KIRCHNER (EDS)

Theory and reform in the European Union, 2nd edition

DIMITRIS N. CHRYSSOCHOOU, MICHAEL J. TSINISIZELIS,

KOSTAS IFANTIS AND STELIOS STAVRIDIS

German policy-making and eastern enlargement of the EU during the Kohl era

Managing the agenda?

STEPHEN D. COLLINS

The European Union and the Cyprus conflict

Modern conflict, postmodern union

THOMAS DIEZ

The time of European governance

MAGNUS EKENGREN

Greece in a changing Europe

Between European integration and Balkan disintegration?

KEVIN FEATHERSTONE AND KOSTAS IFANTIS (EDS)

An introduction to post-Communist Bulgaria

Political, economic and social transformation

EMIL GIATZIDIS

The new Germany and migration in Europe

BARBARA MARSHALL

Turkey's relations with a changing Europe

MELTEM MÜFTÜLER-BAC

The road to the European Union, volume 2

VELlo PETTAI AND JAN ZIELONKa (EDS)

Righting wrongs in Eastern Europe

ISTVAN POGANY

The road to the European Union, volume 1

The Czech and Slovak Republics

JACQUES RUPNIK AND JAN ZIELONKA (EDS)

Two tiers or two speeds?

The European security order and the enlargement of the European Union and NATO JAMES SPERLING (ED.)

Recasting the European order

Security architectures and economic cooperation

JAMES SPERLING AND EMIL KIRCHNER

The emerging Euro-Mediterranean system

DIMITRIS K. XENAKIS AND DIMITRIS N. CHRYSSOCHOOU 
Amikam Nachmani

\section{TURKEY: FACING}

A NEW MILLENNIUM

\section{COPING WITH \\ INTERTWINED CONFLICTS}

MANCHESTER UNIVERSITY PRESS

Manchester and New York

distributed exclusively in the USA by Palgrave 
Copyright $\odot$ Amikam Nachmani, 2003

The right of Amikam Nachmani to be identified as the author of this work has been asserted by him in accordance with the Copyright, Designs and Patents Act 1988.

Published by Manchester University Press Oxford Road, Manchester M13 9NR, UK and Room 400, 175 Fifth Avenue, New York, NY 10010, USA www.manchesteruniversitypress.co.uk

Distributed exclusively in the USA by Palgrave, 175 Fifth Avenue, New York, NY 10010, USA

Distributed exclusively in Canada by UBC Press, University of British Columbia, 2029 West Mall, Vancouver, BC, Canada V6T 1Z2

British Library Cataloguing-in-Publication Data

A catalogue record for this book is available from the British Library

Library of Congress Cataloging-in-Publication Data applied for

ISBN 0719063701 hardback

First published 2003

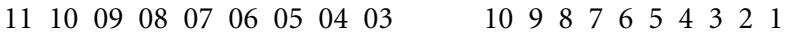

Typeset in Minion with Lithos

by Northern Phototypesetting Co Ltd, Bolton

Printed in Great Britain

by Biddles Ltd, Guildford and King's Lynn 